\title{
"Ele está no meio de nós" Teologia da presença de Cristo em sua Igreja, segundo Santo Agostinho
}

\author{
Orientador: Luiz Fernando Ribeiro Santana \\ Mestrando: Roan Cleber Ataide Souza \\ Área de Concentração: Teologia Sistemático-Pastoral \\ Linha de Pesquisa: Fé e Cultura
}

A presença de Deus se evidencia no mundo de diversas formas. Ela se tornou ainda mais manifesta quando Deus irrompeu na história e selou com Israel uma aliança. Amorosamente escolhido, o povo da antiga aliança pôde experimentar a cuidadosa presença do Senhor através de inúmeros "sinais-sacramentos". Segundo o relato das Escrituras e o testemunho das primeiras comunidades cristãs, essa mesma presença se fez carne em Jesus Cristo, o Verbo eterno do Pai. Por meio de gestos e palavras, Jesus revelou aos homens a presença de Deus e, na potência de seu Espírito, lhes tornou membros de seu Corpo, a Igreja. As primeiras gerações cristãs, conscientes de serem herdeiras da fé do antigo Israel, procuravam - sobretudo em suas assembleias litúrgico-cultuais - experimentar e testemunhar, diante do mundo, o Cristo ressuscitado, sinal privilegiado da presença de Deus. Nele, por meio dele e com ele, doravante, o ser humano e o restante da criação carregam em si a potência de serem sacramento da presença do eterno no tempo. Segundo Santo Agostinho, isso se aplica, de modo particular, ao mistério e à missão da Igreja - "corpo-presença" de Cristo na história. Diz o santo Doutor que, no regime da nova aliança, este no qual vivemos, convém falar na presença e ação de um "Cristus totus". Trata-se do "Cristo todo inteiro": o Cristo - "plenitude" e "primogênito", por meio do qual todos os seres são reconciliados com Deus - e seu Corpo, a Igreja, cooperadora de Cristo em seu agir reconciliante. O Concílio Vaticano II, por sua vez, reverberando o pensamento do Doutor da Graça, consegue captar e reconhecer que a Igreja tem um importante papel no processo de reconcilação-deificação do criado. A Igreja, sacramento de Cristo, poderia, 
então, ser chamada de "Corpus totum". E tudo em vista do mais profundo e original anelo do Deus-Amor: ser presença geradora de comunhão em tudo o que existe.

Palavras-chave: Teologia litúrgica. Presença. Igreja. 